\title{
“COMPARATIVE STUDY OF RECURRENCE RATE OF PTERYGIUM EXCISION WITH BARE SCLERA TECHNIQUE AND CONJUNCTIVAL AUTOGRAFT IN NALAGONDA DIST"
}

Arvind Ram, P. Sudhir Babu, G. Amaresh

1. Assistant Professor. Department of Ophthalmology, Kamineni Institute of Medical Sciences. Narketpally.

2. Associate Professor. Department of Ophthalmology, Kamineni Institute of Medical Sciences. Narketpally.

3. Professor \& HOD. Department of Ophthalmology, Kamineni Institute of Medical Sciences. Narketpally.

\section{CORRESPONDING AUTHOR:}

Dr. Arvind Ram,

Assistant Professor,

Dept of Ophthalmology,

Kamineni Institute of Medical Sciences,

Narketpally-508254, Nalagonda dist, Andhra Pradesh.

E-mail: drarvindkumar1010@gmail.com

ABSTRACT: BACKGROUND: Pterygium is a fibrovascular subepithelial growth of actinically damaged bulbar conjunctival tissue extending across the limbus and onto the cornea. It is a common external eye disease, affecting different populations especially in tropical \& subtropical regions. It is commonly seen in those patients who have been living in hot climate and may represent a response to chronic dryness and ultraviolet exposure. MATERIAL \& METHODSPatient presenting to the outpatients clinic of Ophthalmology Department in Kamineni Institute of Medical Sciences (KIMS), Narketpally with pterygium from January 2011 to December 2012 were included in our study. 90 patients were included in the study after taking informed written consent. These patients were divided into two groups, group -A patients underwent bare sclera excision \& group-B patients underwent bare sclera excision with conjunctival autograft. Each patient was followed for a regular interval of 1 month,3 months \& 6 months. The primary outcome was to measure pterygium recurrence, defined as the $2 \mathrm{~mm}$ or more re-growth of the fibrovascular tissue over the cornea. The definition of pterygium recurrence varies among studies.. RESULTS-Total 90 patients were included in our study. Out of 90 cases,50(55.6\%) cases were female \& $40(44.4 \%)$ cases were male. 36 patients were operated with bare sclera technique \& 54 patients were with conjunctival autograft. $14(38.9 \%)$ recurrence was noted in group-A \& 6(11.1\%) developed recurrence in group-B. The ages of the patients ranged from 20 65 years. CONCLUSION-It has been concluded that conjunctival autograft is better and safe technique for prevention of recurrence of pterygium as compared to bare sclera technique.

KEY WORDS: Pterygium, Bare Sclera, Autograft, Recurrence

INTRODUCTION: Pterygium is an elastotic degeneration of subconjunctival tissue. It appears as a fibrovascular, wing shaped fleshy mass in interpalpebral fissure extending across the limbus and invading into the cornea ${ }^{1}$.It is most commonly seen on nasal side rather than temporal ${ }^{2}$.It consists of a cap, head \& body. The cap represents that the pterygium is progressive in nature .There is no sex predilection. The cause of pterygium is exactly not known but those who work outdoors in hot \& dusty climate are more prone to develop pterygium ${ }^{3}$. Exposure to ultraviolet rays is the most common associated factor, especially UVR-A \& UVR-B(290-400nm) is considered as most dangerous ${ }^{4}$. There is also a hereditary factor playing role in occurrence of pterygium. ${ }^{5}$ Its worldwide prevalence reported is $2 \%$ to $7 \%{ }^{6}$. Leonard P.K.Ang (2005) reported 
prevalence rate ranging from $0.3 \%$ to $29 \%$ in their study 7 .The patient usually complains of foreign body sensation due to conjunctival irritation and diminution of vision due to corneal astigmatism. The main complication to all pterygium excised patients is recurrence which is more difficult to control ${ }^{8}$. It is believed that surgical trauma and post operative inflammation activates subconjunctival fibroblasts and vascular proliferation resulting in deposition of extracellular matrix proteins which contributes to recurrence of the lesion'. The mainstay of treatment of pterygium is surgical excision. Most ophthalmologists define pterygium recurrence as corneal recurrence, which include re-growth of fibrovascular pterygium-like tissue crossing the limbus onto the cornea, fibrovascular recurrence attaining the same degree of corneal encroachment as the original lesion, or re -growth exceeding $1 \mathrm{~mm}$ onto the cornea. Recurrence and graft failure were related to lack of surgical experience in performing conjunctival grafting Since earlier days Bare sclera technique is widely used because it is safe, simple and less time consuming but unfortunately has got high recurrence rate. Conjunctival autograft is preferred over bare sclera technique due to its low recurrence rate. Jaros $P A$ (1988) reported recurrence rate of $24 \%$ to $89 \%$ in bare sclera technique ${ }^{10}$ Prabhasawat $P$ (1997) reported that autologous conjunctival autograft is the best method, giving both low recurrence rate \& higher safety margin ${ }^{11}$. Kenyon et al, first described a conjunctival autograft in 1985.They documented a recurrence rate of $5.3 \%{ }^{12}$. Apart from conjunctival autograft, there are various other techniques used to achieve low recurrence rate such as amniotic membrane transplantation, limbal autograft and fibrin glue. Mashhoor F( 2002) documented that both conjunctival and limbalconjunctival autograft transplantation are technically demanding and time consuming , and paying attention to surgical details such as complete removal of episcleral scar tissue, harvesting a graft of proper size and free of Tenon's tissue, and meticulous dissection and handling of the graft tissue is important ${ }^{13}$.

MATERIALS AND METHODS: Patient presenting to the outpatients clinic of Ophthalmology Department in Kamineni Institute of Medical Sciences (KIMS) Narketpally, Nalgonda District(AP) with pterygium from January 2011 to December 2012 were included in our study. Total 90 patients were included in this study. Out of 90 patients, 50 patients were female and 40 patients were male. These patients were randomly divided into two groups, Group -A underwent bare sclera technique \& Group-B patients underwent conjunctival autograft. All patients were operated under local anaesthesia with infiltration of $2 \%$ xylocaine with adrenaline. $0.25 \mathrm{cc} .2 \%$ xylocaine was infiltrated into the head of pterygium\& $0.5 \mathrm{cc}$ of the same injection was infiltrated at the superotemporal conjunctiva of the same eye. All procedures were done by same surgeon.

In Group-A patients, the pterygia were excised, the abnormal tissues were cleared from the cornea \& conjunctiva with crescent and conjunctival scissor respectively and cauterized the bare sclera to achieve the hemostasis and left it as such. Antibiotic eye ointment was instilled and patched for 24 hours.

In Group-B patients, after excision of pterygium, the bare area was measured with calliper and autograft of the same size and free of tenon's tissue was fashioned from the supero temporal region of the bulbar conjunctiva of the same eye and sutured with 10-0 nylon to the surrounding conjunctiva and antibiotic drops and ointment was instilled in the eye and patched for 24 hrs. Each patient was followed up regular intervals of 1 month, 3 months \& 6 months. 
The primary outcome was to measure pterygium recurrence. The recurrence was defined as re growth of $2 \mathrm{~mm}$ or more fibrovascular tissue over the cornea. The definition of pterygium recurrence varies among studies.

RESULTS: Corneal epithelial defects healed within 1 week and graft sites within 10 days in both groups. All grafts showed mild transient edema which usually resolved in 3-4 days. Visual acuity improved by two lines or more in $26 \%$ of patients in group $\mathbf{A}$ and $39 \%$ of patients in group $\mathbf{B}$. Total 90 patients were included in our study. Out of 90 cases,50(55.6\%) cases were female \& $40(44.4 \%)$ cases were male. 36 patients were operated with bare sclera technique $\& 54$ patients were with conjunctival autograft. 14 (38.9\%) recurrence was noted in group-A \& 6(11.1\%) developed recurrence in group-B. The age group of the patients ranged between 20-65 years. The recurrence of pterygium was observed more in younger patients. The complications noted in bare sclera technique included scleral necrosis in 1 patient (1.1\%) within 1 month, conjunctival cyst in 3 cases (3.3\%) within 6 months, sub-tenon granuloma in 4 cases (4.4\%) within 1 month and Symblepharon in 1 case (1.1\%) within 12 months. Complication after free conjunctival auto graft were graft edema in 2 cases $(2.2 \%)$ within 1 week which treated by medically, graft retraction in 3 patients $(3.3 \%)$ in next post-operative day which had regrafted and sub-tenon granuloma in 3 cases (3.3\%) within 1 month. There were no major complications threatening visual acquity in the surgical patients.

DISCUSSION: In our study pterygium was more common in females than males with M:F 0.8:1 but Nazullah khan et al (2010) reported that pterygium was more common in males, this could be attributed to regional differences.

Visual acuity improved by two lines or more in $26 \%$ of patients in group A and $39 \%$ of patients in group $\mathbf{B}$.

Recurrence rate in our study were $38.9 \%$ in bare sclera technique and $11.1 \%$ in conjunctival autograft but Kenyon et al (1985) reported 5.3\% recurrence rate in conjunctival autograft in their study. Nazullah khan et al (2010) were documented 36.6\% recurrence rate with bare sclera technique and $8.8 \%$ with conjunctival autograft 14 .

In a study done by, Lewallen $S$ (1989) recurrence rate of $40 \%$ was observed with the bare sclera technique and 7\% with conjunctival autografts ${ }^{15}$. Riordan-Eva et al (1993) of Moorfields Eye Hospital London supported Lewallen S finding when they reported a statistically significant reduction in recurrence rate following conjunctival autografting for pterygium. They documented a probability of recurrences of $14 \% 16$. Fahmi et al (2005) reported $13.33 \%$ recurrence rate with conjunctival autograft ${ }^{17}$. Solomon et al (2001) reported that by incorporating a larger removal of subconjunctival fibrosis tissue and injection of long acting steroids, amniotic membrane grafts achieved a lower recurrence rate of 3.0\%, compatible with $2.6 \%$ of conjunctival auto grafts published by Prabhasawat (1997)18. Mohammad Saleem et al (2004)also show high results of recurrence $30 \%$ in pterygium with simple excision ${ }^{19}$.Ashok Kumar Narsani et al (2008) reported that there was $7.69 \%$ recurrences in Conjunctival Auto Graft 20 .

CONCLUSION: With this study we conclude that pterygium recurrence is related to pterygium morphology and fleshiness. Conjunctival autografting for primary and recurrent pterygium is effective in reducing pterygium recurrence compared with bare sclera excision. Conjunctival 
autograft was better and safe technique for prevention of recurrence after pterygium surgery as compared to bare sclera technique and is associated with improvement of visual acuity.

\section{REFERRENCES:}

1. Wong AK, Rao SK, Leug At, Poon AS, Lam DS. Inferior Limbal - Conjunctival autograft transplantation for recurrent pterygium. Indian J Ophthalmol 2000; 48; 21-4.

2. Michael R, Edward GJ, Holland. Management of pterygium. In: Krachmer JH, Mannis MJ, Holland EJ. Cornea Vol 3: Surgery of the cornea and conjunctiva. New york: Mosby. 1997; 1873-85

3. Nakaishi H, Yamamoto M, I Shida M. Pingueculae and pterygia in motorcycle policeman.Ind Health 1997; 35:325-9.

4. Taylor HR, West SK, Rosenthal FS, et al. Corneal changes associated with chronic UV irradiation. Arch Ophthalmol.1989;

5. Booth F. Heredity in one hundred patients admitted for excision of pterygia. Aust N Z J Ophthalmol 1985; 13:59-61.

6. Donnenfeld ED, Perry HD, Fromer S, Doshi S, Solomon R, Biser S. Subconjuctivalmitomycin $\mathrm{C}$ as adjunctive therapy before pterygium excision. Ophthalmology 2003;110:1012-1026.

7. Ang LP, Tan DT, Cajucom-Uy H, Beuerman RW. Autologous cultivated conjunctival transplantation for pterygium surgery. Am J Ophthalmol 2005; 139:611-619.

8. Hirst LW. The treatment of pterygium. Surv. Ophthalmol 2003; 48:145-177.

9. Mutulu FM, Sobaci G, Tatar T, Yildirim E. A comparative study of recurrent pterygiumsurgery. Ophthalmology 1999; 106:817-821.

10. Jaros PA, DeLuise VP. Pingueculae and pterygia. Surg Ophthalmol 1988; 33:41-9.

11. Prabhasawat $P$, Barton K, Burkett G. Comparison of conjunctival autografts, amniotic membrane grafts, and primary closure for pterygium excision. Ophthalmology 1997;104: 974-85.

12. Kenyon KR, Wagoner MD, Hettinger ME. Conjunctivalautograft transplantation for

13. Advanced and recurrent pterygium. Ophthalmology 1985;92:1461-70.

14. Mashhoor F. Al Fayez, MD, FRCS Limbal versus ConjunctivalAutograft Transplantation for Advanced and Recurrent PterygiumOphthalmology 2002;109:1752-1755 @ 2002 by the American Academy of Ophthalmology.

15. Nazullah Khan, Mushtaq Ahmad, Abdul Baseer, Naimatullah Khan Kundi; To Compare the Recurrence Rate of Pterygium Excision with Bare-sclera, Free Conjunctival Auto Graft and Amniotic Membrane Grafts; Pak J Ophthalmol 2010, Vol. 26 No. 3

16. Lewallen S. A randomised trial of conjunctival autografting for pterygium in the tropics. Ophthalmology 1989; 96:1612-4.

17. Riordan-Eva P, Kielhorn I, Ficker LA, Steele AD,Kirkness CM. Conjunctival autografting in the surgical management of pterygium. Eye 1993; 7:634-8.

18. Fahmi M S, Sayed J, Ali M. After removal of pterygium role of Mitomycin and conjunctival autograft. Ann Abbasi Shaheed Hosp KMD Coll 2005; 10:757-61.

19. Soloman A, Pires RTF, Tseng SCG. Amniotic membrane transplantation after extensive removal of primary and recurrent pterygia. Ophthalmology. 2001; 108: 449-60.

20. Saleem M, Muhammad L, Ziaul Islam. Pterygium and dry eye, a clinical study. J Postgrad Med Inst 2004; 18: 558-62. 
21. Narsani AK, Jatoi SM, Gul S, et al. Treatment of Primary Pterygium with Conjunctival Auto graft and Mitomycin C. A Comparative Study Journal of Liaquat University of Medical \& Health Sciences (JLUMHS)l Hyderabad. 2008.

Table .No. 1 Gender Distribution

\begin{tabular}{|c|c|c|}
\hline Gender & $\mathbf{N}=\mathbf{9 0}$ & $\mathbf{\%}$ \\
\hline Male & 40 & $44.4 \%$ \\
\hline Female & 50 & $55.6 \%$ \\
\hline Total & 90 & $100 \%$ \\
\hline
\end{tabular}

Table .No. 2 Recurrence Rate

\begin{tabular}{|c|c|c|}
\hline Group & $\mathbf{N}=\mathbf{9 0}$ & Recurrence rate \\
\hline Group - A & 36 & $14(38.9 \%)$ \\
\hline Group -B & 54 & $6(11.1 \%)$ \\
\hline
\end{tabular}

Table .No. 3 Complications

\begin{tabular}{|c|c|c|c|}
\hline Bare sclera & No. of cases & ConjunctivalAutograft & No. of cases \\
\hline Conjunctival cyst & $3(3.3 \%)$, & Graft edema & $2(2.2 \%)$ \\
\hline Scleral necrosis & $1(1.1 \%)$ & Graft Retraction & $3(3.3 \%)$ \\
\hline $\begin{array}{c}\text { Sub-tenon's } \\
\text { Granuloma }\end{array}$ & $4(4.4 \%)$ & $\begin{array}{c}\text { Sub-tenon's } \\
\text { Granuloma }\end{array}$ & $3(3.3 \%)$. \\
\hline Symblepharon & $1(1.1 \%)$ & ----- & -------- \\
\hline
\end{tabular}




\section{ORIGINAL ARTICLE}

Figure 1.Conjunctival Autograft

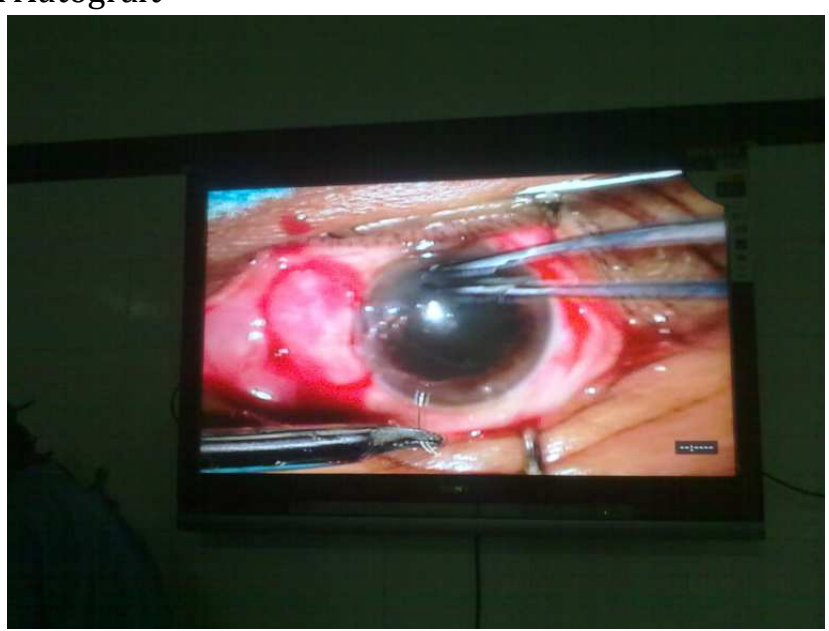

Figure 2. Post OP Follow up of conjunctival autograft

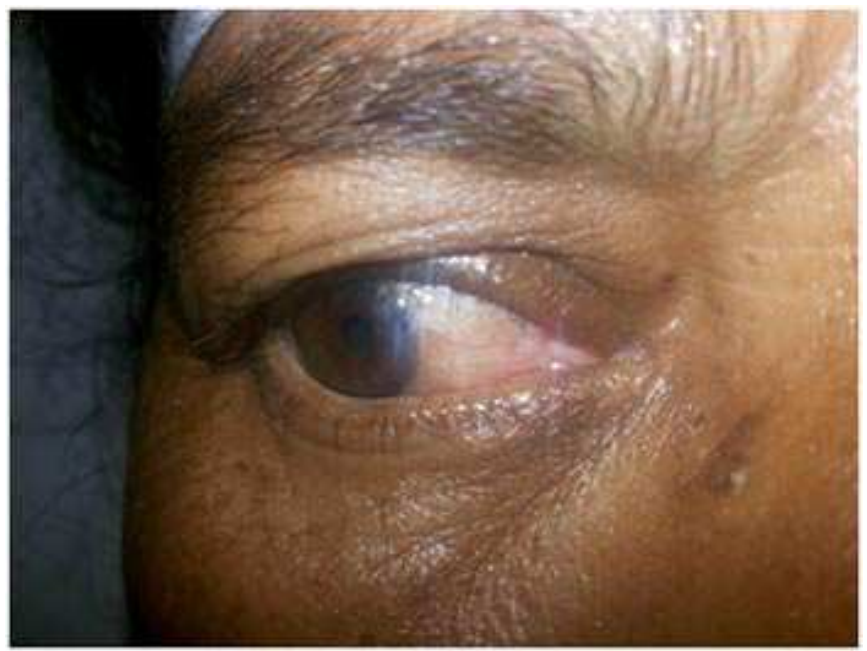

Figure 3.Progressive Pterygium

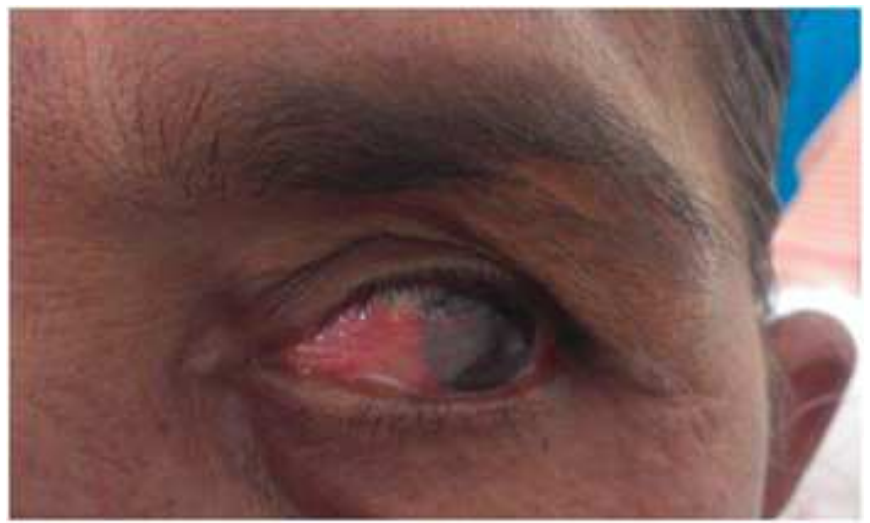

